\title{
Analysis of selected fungi variation and its dependence on season and mountain range in southern Poland-key factors in drawing up trial guidelines for aeromycological monitoring
}

\author{
Wojciech Pusz • Ryszard Weber • Andrzej Dancewicz • \\ Włodzimierz Kita
}

Received: 2 May 2017 / Accepted: 20 September 2017 /Published online: 27 September 2017

(C) The Author(s) 2017. This article is an open access publication

\begin{abstract}
The aim of the study was to identify fungal spores, in particular plant pathogenic fungi, occurring in the air in selected mountain ranges. The results revealed not only the array of fungal species migrating with air currents from the Czech Republic and Slovakia but also how the season of the year affects the distribution of spores. Such studies may lay a foundation for future aeromycological monitoring, in accordance with the requirements for integrated plant protection. Aeromycological research was carried out between 2013 and 2016 at 3-month intervals in mountainous areas along the southern borders of Poland: the Bieszczady, the Pieniny, the Giant Mountains (Karkonosze) and the Babia Góra Massif. The research relied on impact method employing Air Ideal 3P sampler, which, by drawing in atmospheric air, also collects fungal spores. Regardless of altitudinal zonation, the changing weather conditions appeared to be the main reason for the variations in the number of the fungal spores under study in those years.
\end{abstract}

W. Pusz $(\bowtie) \cdot$ W. Kita

Department of Plant Protection, Wroclaw University of Environmental and Life Sciences, Plac Grunwaldzki 24A, 50-363 Wroclaw, Poland

e-mail: wojciech.pusz@upwr.edu.pl

R. Weber

Institute of Soil Science and Plant Cultivation-National Research Institute, ul. Orzechowa 62, 50-540 Wroclaw, Poland

A. Dancewicz

Institute of Meteorology and Water Managemen - National

Research Institute, ul. Parkowa 30, 56-616 Wroclaw, Poland
Keywords Aeromycological monitoring $\cdot$ Fungal diseases $\cdot$ Pathogenic fungi $\cdot$ Statistical methods

\section{Introduction}

Fungi, present everywhere, including the air, are one of the elements of bioaerosol and are capable of surviving in this environment for an extended period of time (Dowd and Maier 1999). Airborne spores and mycelium are currently regarded as posing potential threat to humans suffering from allergies and may lead to a variety of health problems including asthmatic symptoms (Kurup et al. 2002; Asan et al. 2004). Understandably, one of the main objectives of aeromycological investigations is to confirm the presence of fungal spores which may adversely affect not only humans but also animals (Asan et al. 2004; Bugajny et al. 2005; Klarič and Pepeljnjak 2001; Topbas et al. 2006; Palmas and Cosentino 2009; Ianovici et al. 2011; Pusz et al. 2015). Fungi may additionally exert a detrimental influence on plants and spread infections (Meredith 1973; Dowd and Maier 1999; Jędryczka 2014). Furthermore, atmospheric air may carry parts of fungi which are capable of producing toxins, e.g. mycotoxins with possible negative impact on human and animal health (Raisi et al. 2012).

Consequently, some authors regard aeromycological studies as an element of an 'early warning' signalling plant disease (Dowd and Maier 1999; Pusz et al. 2013; Jędryczka 2014). Almaguer-Chávez and his team (2012) studied fungi concentrations colonising rice 
plantations and proved that aeromycological monitoring may be instrumental in signalling plant disease; this was corroborated by other researchers (Leyronas and Nicot 2012). Such studies may provide a database for mapping the distribution and/or occurrence of fungal spores which are both harmful to humans and pathogenic for plants (Toamssetti et al. 2011). This may be of profound importance in the case of the fungi which can be carried by wind over long distances (Palti and Cohen 1980; Leyronas and Nicot 2012) despite natural barriers such as high mountains (Nagarajan and Saharan 2007; Vaish et al. 2011; Pusz et al. 2013). Several authors thus reported, in mountainous areas, a number of fungal species pathogenic for plants. Klarič and Pepeljnjak (2001) identified airborne fungal spores of the genus Cladosporium, Alternaria, as well as Fusarium, Sclerotinia and Botrytis at 800-900 m above sea level, in the mountains near Zagreb, which was later confirmed by others (Pepeljnjak and Šegvič 2003; Magyar et al. 2012; Pusz et al. 2013). Aeromycological research in mountainous terrain constitutes unfortunately only an insignificant fraction of all aeromycological studies (Xia et al. 2012; Pusz et al. 2013).

The aim of this study was to determine the array of airborne fungal species, in particular those which are pathogenic for plants, occurring in selected mountain ranges. The results obtained during the study may be invaluable in establishing what fungi are carried with the air from the Czech Republic and Slovakia and how seasons of the year affect the distribution of fungal spores. Such analysis may in the future provide a springboard for aeromycological monitoring, which is in accordance with the statutory requirements imposed on integrated plant protection.

\section{Material and methods}

The aeromycological studies were conducted at 3month intervals in the years 2013-2016, close to Poland's southern borders (Fig. 1). The precise locations were the following mountain ranges: the Bieszczady (Mount Tarnica $1346 \mathrm{~m}$ above sea level, 49 ${ }^{\circ}$ 04.483' $\mathrm{N}, 22^{\circ} 43.575^{\prime} \mathrm{E}$ ), the Pieniny (Mount Palenica $722 \mathrm{~m}$, $49^{\circ} 42.552^{\prime} \mathrm{N}, 20^{\circ} 48.066^{\prime} \mathrm{E}$ ), the Tatras (Mount Kasprowy Wierch 1997 m, 49 $13.5461^{\prime \prime}$ N, 19 59' 004' E), the Babia Góra Massif (Mount Babia Góra 1725 m.n.p.m. (49 $\left.34.392^{\prime} \mathrm{N}, 19^{\circ} 31.866^{\prime} \mathrm{E}\right)$ and the
Karkonosze (Mount Śnieżka-1603 m.n.p.m. (50 $\left.44.172^{\prime} \mathrm{N}, 15^{\circ} 44.394^{\prime} \mathrm{E}\right)$.

Data collection

The research was performed employing impact method and using Air Ideal 3P. Drawing in the air, the device collects as well airborne fungal spores, which are then transferred onto petri dish and fed on growth medium potato dextrose agar (PDA, Biocorp.) with the addition of citric acid. Placed $1.5 \mathrm{~m}$ above ground, the device was set to collect 5, 100 and 1501 volume samples. All the measurements were repeated three times; each sample was deposited on nine petri dishes. These were stored at room temperature $\left(20-22^{\circ}\right)$ over the period of 7 to 10 days. The next step to follow was to establish which species the grown fungi belonged to, and this was done on the strength of the morphological features defined by Pitt and Hocking (2009) and Watanabe (2011), and then to determine the number of colonies. The number of colonies grown on each dish was calculated for one cubic metre of air according to the formula

$X=(a \times 1000) / V$

where $X$ is the number of colony-forming units (CFUs) in $1 \mathrm{~m}^{3}$ of air, $a$ is the total of fungal colonies which developed on petri dish from airborne spores, and $V$ is the volume of drawn atmospheric air, expressed in litres.

Statistical analyses

Out of 37 fungal species whose spores were identified in the mountainous belt of southern Poland, 12 most ubiquitous species were selected for the statistical analysis: Alternaria alternata, Auerobasidium pullulans, Cladosporium cladosporioides, Cladosporium herbarum, Fusarium equiseti, Gliocladium catenulantum, Penicillium notatum, Penicillium purpurgenum, Penicillium waksmani, Penicillium vermiculatum, Sclerotinia sclerotiorium and Trichotecium roseum. Log-linear analysis was performed to correlate the number of species under study, the year, the season and the mountains range. Some considerable disparities between the figures for the species under study and the expected figures, as revealed during the analysis, are indicative of a set of connections 


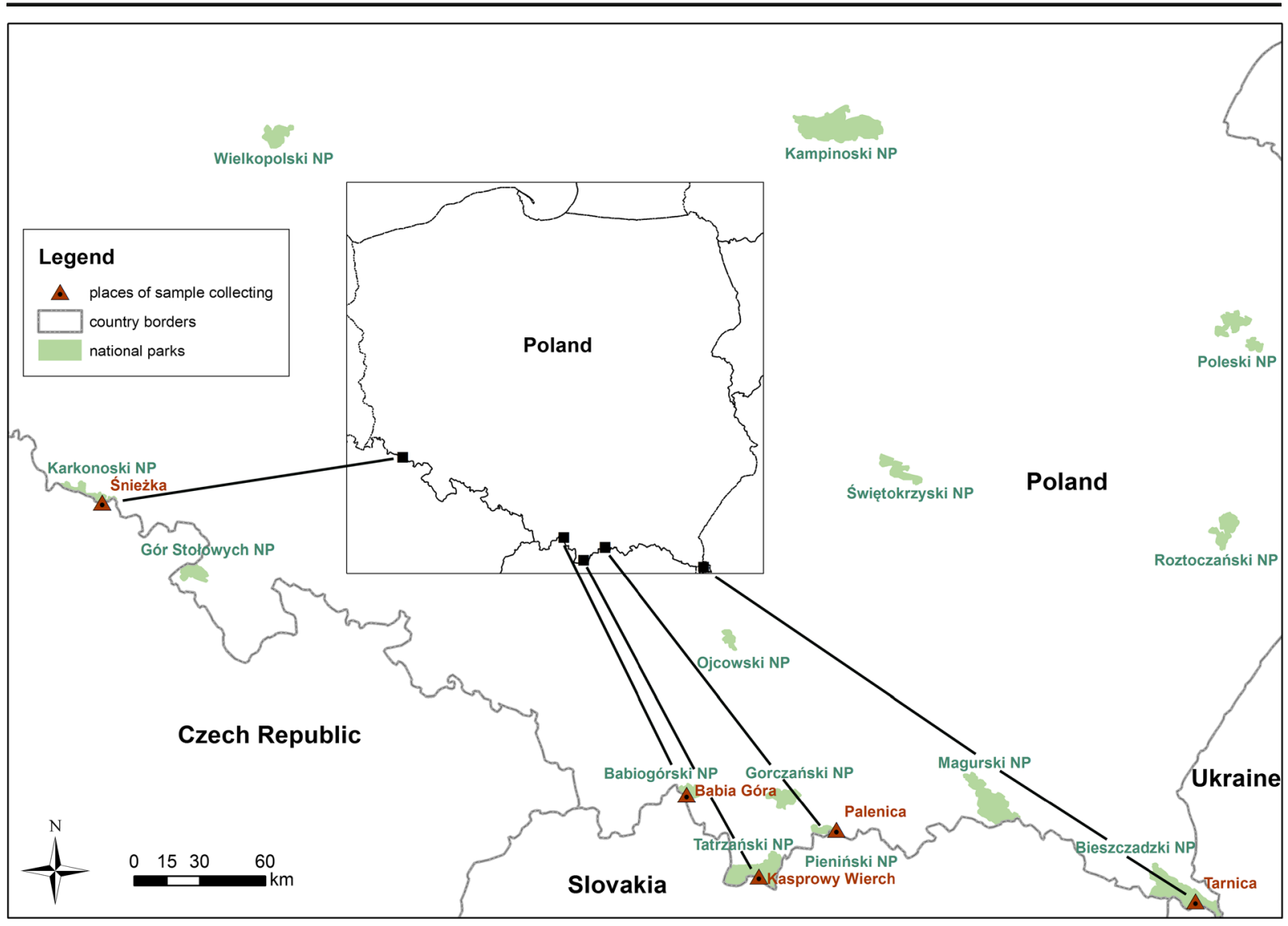

Fig. 1 Sample collection site

among the variables. The expected figures were converted from a logarithmic scale to a linear scale, yielding a model which may simply be based on a formula

$\operatorname{Ln}\left(E_{i j}\right)=M+\lambda_{i}^{X}+\lambda_{j}^{Y}+\lambda_{i j}^{X Y}$

where $E_{i j}$ is the expected frequency in cell, $M$ is the general average based on equal cell count, $\lambda_{i}^{X}$ is the $i t h-$ row effect for variable $X, \lambda_{j}{ }^{Y}$ is the $j$ th-column effect for variable $Y$, and $\lambda_{i j}{ }^{X Y}$ is the interaction of $i$ th-row effect and $j$ th-column effect for variables $X$ and $Y$.

The log-linear model allows a verification of the hypothesis predicting no interaction between two or more elements of the experiment. Discarding immaterial interactions, it also facilitates an examination of the impact of each factor on the changes occurring within the fungal population under study. The next step was to examine the patterns of the changing fungal species count in relation to the season of the year and mountain range; this was done by performing correspondence analysis. This analysis enables an accurate assessment of the way fungal species depend on other elements of the research and is instrumental in converting a 40D model, i.e. 2 years $\times 4$ seasons $\times 5$ mountains, to $2 \mathrm{D}$ graphs transferring comprehensively as much information on the changes as possible.

\section{Results}

The weather conditions in the locations and the times of sampling are shown in Table 1. The temporary parameters of the ambient air may vary widely, which is perfectly explicable in terms of the extremely long distances between the locations. It is noteworthy that the collection of the data coincided almost invariably with the days when there was no precipitation, air humidity was often very low and so was wind speed, except the highest elevations: Mount Kasprowy Wierch and Mount Śnieżka.

Two series of checks were conducted in 2013: in July, which is a summer month, and in November, 
Table 1 Weather conditions in the location where and at the time when the samples were collected

\begin{tabular}{|c|c|c|c|c|c|c|c|c|}
\hline $\begin{array}{l}\text { Number } \\
\text { of } \\
\text { sampling }\end{array}$ & Date & Hour & Fieldwork & $\begin{array}{l}\text { Meteorological } \\
\text { station }\end{array}$ & $\begin{array}{l}\text { Temperature } \\
\left({ }^{\circ} \mathrm{C}\right)\end{array}$ & $\begin{array}{l}\text { Humidity } \\
(\%)\end{array}$ & Wind $(\mathrm{m} / \mathrm{s})$ & $\begin{array}{l}\text { Precipitation } \\
(\mathrm{mm})\end{array}$ \\
\hline \multirow[t]{5}{*}{ No. 1} & 22 July 2013 & 9.00 & Tarnica & Wetlina & 18 & $67-72$ & NW-1-2 & \\
\hline & 22 July 2013 & 13.00 & Palenica & Krościenko & 23 & $40-45$ & $N W-3-4$ & \\
\hline & 22 July 2013 & 15.00 & $\begin{array}{c}\text { Kasprowy } \\
\text { Wierch }\end{array}$ & $\begin{array}{c}\text { Kasprowy } \\
\text { Wierch }\end{array}$ & 13 & $68-71$ & $\mathrm{~N}-3-4$ & \\
\hline & 23 July 2013 & 11.00 & Babia Góra & Zawoja & 20 & $58-63$ & NW-1-2 & \\
\hline & 23 July 2013 & 17.00 & Śnieżka & Śnieżka & 13 & $55-60$ & $\mathrm{~N}-7-9$ & \\
\hline \multirow[t]{5}{*}{ No. 2} & $\begin{array}{l}\text { 06 November } \\
2013\end{array}$ & 9.00 & Tarnica & Wetlina & $4-5$ & 100 & Wind - calm-1 & \\
\hline & $\begin{array}{l}06 \text { November } \\
2013\end{array}$ & 13.00 & Palenica & Krościenko & $6-7$ & $75-80$ & Wind - calm-1 & \\
\hline & $\begin{array}{l}\text { 06 November } \\
2013\end{array}$ & 15.00 & $\begin{array}{c}\text { Kasprowy } \\
\text { Wierch }\end{array}$ & $\begin{array}{c}\text { Kasprowy } \\
\text { Wierch }\end{array}$ & -6 & 100 & NW-10-11 & \\
\hline & $\begin{array}{l}\text { 07 November } \\
2013\end{array}$ & 11.00 & Babia Góra & Zawoja & 10 & $82-85$ & SW-1-2 & Light rain \\
\hline & $\begin{array}{l}07 \text { November } \\
2013\end{array}$ & 17.00 & Śnieżka & Śnieżka & 5 & 100 & SW-17-20 & Light rain \\
\hline \multirow[t]{5}{*}{ No. 3} & 12 January 2014 & 9.00 & Tarnica & Wetlina & -1 & $82-85$ & NW-2-3 & \\
\hline & 12 January 2014 & 13.00 & Palenica & Krościenko & 1 & $84-87$ & $N W-3-4$ & \\
\hline & 12 January 2014 & 15.00 & $\begin{array}{l}\text { Kasprowy } \\
\text { Wierch }\end{array}$ & $\begin{array}{c}\text { Kasprowy } \\
\text { Wierch }\end{array}$ & -10 & $90-93$ & NW- $10-12$ & \\
\hline & 13 January 2014 & 11.00 & Babia Góra & Zawoja & $1-2$ & $52-58$ & $\mathrm{SE}-1$ & \\
\hline & 13 January 2014 & 17.00 & Śnieżka & Śnieżka & $1-2$ & $80-85$ & NW-9-19 & \\
\hline \multirow[t]{5}{*}{ No. 4} & 05 April 2014 & 9.00 & Tarnica & Wetlina & 5 & $73-78$ & Wind - calm-1 & \\
\hline & 05 April 2014 & 13.00 & Palenica & Krościenko & 11 & $55-60$ & NW-5-6 & \\
\hline & 05 April 2014 & 15.00 & $\begin{array}{l}\text { Kasprowy } \\
\text { Wierch }\end{array}$ & $\begin{array}{l}\text { Kasprowy } \\
\text { Wierch }\end{array}$ & $2-3$ & $98-100$ & $\mathrm{SW}-4-5$ & \\
\hline & 06 April 2014 & 11.00 & Babia Góra & Zawoja & 8 & $74-77$ & Wind - calm-1 & \\
\hline & 06 April 2014 & 17.00 & Śnieżka & Śnieżka & 2 & 100 & NW-11-12 & \\
\hline \multirow[t]{5}{*}{ No. 5} & 30 June 2014 & 9.00 & Tarnica & Wetlina & 18 & $85-90$ & $E-2-3$ & \\
\hline & 30 June 2014 & 13.00 & Palenica & Krościenko & 18 & $85-90$ & $\mathrm{SE}-1-2$ & \\
\hline & 30 June 2014 & 15.00 & $\begin{array}{c}\text { Kasprowy } \\
\text { Wierch }\end{array}$ & $\begin{array}{l}\text { Kasprowy } \\
\text { Wierch }\end{array}$ & $7-8$ & 100 & $\mathrm{SE}-6-8$ & Rain (storm) \\
\hline & 01 July 2014 & 11.00 & Babia Góra & Zawoja & 13 & $75-80$ & $\mathrm{~S}-1$ & \\
\hline & 01 July 2014 & 17.00 & Śnieżka & Śnieżka & $6-7$ & $90-95$ & $\mathrm{~W}-3-6$ & \\
\hline \multirow[t]{5}{*}{ No. 6} & $\begin{array}{l}07 \text { November } \\
2014\end{array}$ & 9.00 & Tarnica & Wetlina & 13 & $57-60$ & $\mathrm{SE}-4-5$ & \\
\hline & $\begin{array}{l}07 \text { November } \\
2014\end{array}$ & 13.00 & Palenica & Krościenko & 16 & $64-67$ & $\mathrm{SE}-3-4$ & \\
\hline & $\begin{array}{l}07 \text { November } \\
2014\end{array}$ & 15.00 & $\begin{array}{l}\text { Kasprowy } \\
\text { Wierch }\end{array}$ & $\begin{array}{c}\text { Kasprowy } \\
\text { Wierch }\end{array}$ & $5-6$ & $95-100$ & SW-13-14 & \\
\hline & $\begin{array}{l}\text { 08 November } \\
2014\end{array}$ & 11.00 & Babia Góra & Zawoja & 9 & $90-93$ & $\mathrm{SW}-1$ & Light rain \\
\hline & $\begin{array}{l}08 \text { November } \\
2014\end{array}$ & 17.00 & Śnieżka & Śnieżka & $2-3$ & $45-50$ & $\mathrm{~W}-3-6$ & \\
\hline \multirow[t]{4}{*}{ No. 7} & 28 January 2015 & 9.00 & Tarnica & Wetlina & -4 & $90-95$ & Windless & \\
\hline & 28 January 2015 & 13.00 & Palenica & Krościenko & 2 & $63-64$ & SW-1 & \\
\hline & 28 January 2015 & 15.00 & $\begin{array}{c}\text { Kasprowy } \\
\text { Wierch }\end{array}$ & $\begin{array}{l}\text { Kasprowy } \\
\text { Wierch }\end{array}$ & -11 & $91-92$ & SW-6-7 & \\
\hline & 29 January 2015 & 11.00 & Babia Góra & Zawoja & -1 & $65-68$ & $S-4-5$ & \\
\hline
\end{tabular}


Table 1 (continued)

\begin{tabular}{|c|c|c|c|c|c|c|c|c|}
\hline $\begin{array}{l}\text { Number } \\
\text { of } \\
\text { sampling }\end{array}$ & Date & Hour & Fieldwork & $\begin{array}{l}\text { Meteorological } \\
\text { station }\end{array}$ & $\begin{array}{l}\text { Temperature } \\
\left({ }^{\circ} \mathrm{C}\right)\end{array}$ & $\begin{array}{l}\text { Humidity } \\
(\%)\end{array}$ & Wind $(\mathrm{m} / \mathrm{s})$ & $\begin{array}{l}\text { Precipitation } \\
(\mathrm{mm})\end{array}$ \\
\hline & 29 January 2015 & 17.00 & Śnieżka & Śnieżka & -9 & $92-95$ & SW-11-15 & \\
\hline \multirow[t]{5}{*}{ No. 8} & 29 March 2015 & 9.00 & Tarnica & Wetlina & $1-2$ & $87-90$ & NW-1-2 & \\
\hline & 29 March 2015 & 13.00 & Palenica & Krościenko & 10 & $40-43$ & NW-2-3 & \\
\hline & 29 March 2015 & 15.00 & $\begin{array}{c}\text { Kasprowy } \\
\text { Wierch }\end{array}$ & $\begin{array}{c}\text { Kasprowy } \\
\text { Wierch }\end{array}$ & -1 & $95-98$ & $\mathrm{~N}-5-8$ & \\
\hline & 01 March 2015 & 11.00 & Babia Góra & Zawoja & 1 & $70-75$ & NW-2-3 & Light rain \\
\hline & 01 March 2015 & 17.00 & Śnieżka & Śnieżka & -8 & $90-93$ & NW-28-38 & \\
\hline
\end{tabular}

which is an autumn month. In the summer, 14 species of fungi were observed in the Bieszczady Mountains, 7 in the Pieniny Mountains, 4 in the Tatras, 6 in the Beskidy Mountains and 8 in the Karkonosze Mountains. Cladosporium cladosporoides, which causes among others alternaria black spot, constituted the highest proportion of the fungi identified in all the locations, although other species pathogenic for plants were identified as well: Botrytis cinerea, S. sclerotiorium, Rhizoctonia solani and A. alternata.

In the autumn, 12 species were identified in the Bieszczady Mountains, 12 in the Pieniny Mountains, 7 in the Beskidy Mountains, 9 in the Tatras and 5 in the Karkonosze Mountains. The Bieszczady was mainly home to Gliocladium catenulatum; the same was true for the Pieniny, where additionally, Cladosporium cladosporiodes was observed, whereas in the sites, the most ubiquitous fungi were those of the genus Cladosporium.

In 2014, four series of checks were carried out; they spanned all four seasons of the year. January saw four species in the Bieszczady, where C. cladosporioides was the most popular; six species in the Pieniny, where P. notatum had the highest concentration among all the identified fungal spores; three in the Beskidy and one in the Karkonosze. No fungal colonies were observed in the Tatras at that time. In the spring, eight species were identified in the Bieszczady, where A. alternata and C. cladosporioides were most dominant, similarly as in the Pieniny, the Babia Góra Massif and the Karkonosze; eight species were observed in the Pieniny; two in the Tatras, where the most widespread species was $G$. catenulatum; five in the Beskidy and four in the Karkonosze Mountains.

The summer months saw nine species of airborne fungi in the Bieszczady, six in the Pieniny, six in the
Tatras, four in the Beskidy and six in the Karkonosze. In the Bieszczady, Acremonium strictum and B. cinerea made up the highest percentage of the airborne fungi. The Pieniny results showed a similar trend as that in the spring, with A. alternata and C. cladosporioides dominating the samples; these had the same levels of concentration in the Tatras. The Babia Góra Massif was home predominantly to $B$. cinerea airborne spores, while $P$. notatum and $C$. cladosporioides were the most numerous airborne spores in the Karkonosze. The last sample collection was performed in the autumn: 11 airborne species were identified in the Bieszczady, 10 in the Pieniny, 10 in the Tatras, 9 in the Beskidy and 10 in the Karkonosze. The highest share was claimed by C. cladosporioides in the Bieszczady and the Pieniny, G. catenulatum in the Tatras, this and A. strictum in the Babia Góra Massif and C. cladosporioides in the Karkonosze.

The last year of the research witnessed only two sample collections, in the winter and in the spring. The winter data revealed six species in the Bieszczady, four in the Tatras, two in the Babia Góra Massif, two in the Pieniny and two in the Karkonosze. The spring data, on the other hand, revealed 6 species of airborne fungi in the Bieszczady, 5 in the Tatras, 8 in the Pieniny, 10 in the Babia Góra Massif and 4 in the Karkonosze. In the winter, the most numerous airborne fungal spores were those of the genus Cladosporium, with the exception of the Bieszczady, where A. strictum was the most dominant. In the spring, in the Tatras and the Babia Góra Massif, C. cladosporioides took over from other fungi, as $\operatorname{did} G$. catenulatum in other locations.

The analysis of the optimum statistical model assessing the influence of years, seasons and mountain range on the concentrations of fungi was performed by applying chi-squared test to the main results as well as to 
the many interactions among the various elements of the experiment. The computed statistics for the secondorder and third-order model showed considerable quantities; hence, the hypothesis that there is no correlation between the number of fungal spores under study and when (year and season) as well as where (mountain range) the samples were collected had to be rejected at level $p<0.001$. The data revealed considerable fluctuations in the number of fungus species occurring in the mountainous sites under study in different years and seasons, which proves that atmospheric conditions exert a massive impact on the concentrations of the analysed isolates (Table 1). Strong interactions between fungus species and location or time are confirmed by the variations in the number of species identified in spring, summer, autumn and winter across the five mountain ranges.

Tables 2, 3 and 4 show clearly that the seasons at the turn of 2014 were special in terms of a markedly elevated count of fungal spores under study, compared with the summer and autumn of 2014 and with the winter and spring of 2015. The years 2013 and 2014 saw C. cladosporioides as the dominant species, regardless of location; A. alternata and G. catenulantum followed suit. The Babia Góra Massif was a site boasting a remarkably higher number of spores under study, whereas Mount Śnieżka offered the least favourable conditions for the reproduction of these fungi. Looking at Tables 5 and 6 , one can easily notice a rich diversity of the ecosystem in the years when samples were taken: the summer of 2013 was more conducive to a rapid multiplication of spores than the spring, autumn or winter of 2014 (Table 5). Conversely, the weather conditions in the autumn of 2014 were much more favourable for the population in question than those in the summer of that same year, or in the winter and spring of 2015 (Table 6).

In the next part of the paper, we tried to discern regular patterns in the way the factors under study, i.e. year, season and mountain's environment, affect the levels of concentration of the fungi. This was done by correspondence analysis used routinely by Hill (1974), which is frequently referred to as reciprocal averaging or optimal scaling. The $2 \mathrm{D}$ graphs presented in this work successfully transferred, from the original multi-dimensional system, $85.31 \%$ of the total of the environmental variables in the mountain peaks under study. The arrangement of mountain peaks representing individual environments is indicative, on closer inspection, of a pattern where 'Kasprowy Wierch' (the Tatras) is located on the left-hand side of the coordinates (Fig. 2) and constitutes a separate one-element group which differs fundamentally, with regard to the fluctuations in the numbers of the 12 fungal spores under study, from the other group of the mountains, namely 'Palenica' (the Pieniny), 'Tarnica' (the Bieszczady) and 'Śnieżka' (the Karkonosze). The environmental conditions in Kasprowy Wierch were conducive to a more rapid multiplication of

Table 2 Tests of the main effects, marginal and partial associations and the interactions between experiment factors

\begin{tabular}{|c|c|c|c|c|c|}
\hline Effect & Degrees of freedom & $\mathrm{Chi}^{2}$ partial association & Significant level $(p)$ & $\mathrm{Chi}^{2}$ marginal association & Significant level $(p)$ \\
\hline Mountains (1) & 4 & 5388.59 & $<0.001$ & 5388.59 & $<0.001$ \\
\hline Years (2) & 1 & 109.02 & $<0.001$ & 109.02 & $<0.001$ \\
\hline Seasons (3) & 3 & $11,075.71$ & $<0.001$ & 1175.71 & $<0.001$ \\
\hline Fungus species (4) & 11 & $30,558.43$ & $<0.001$ & $30,558.43$ & $<0.001$ \\
\hline $1 \times 2$ & 4 & 1261.0512 & $<0.001$ & 1261.05 & $<0.001$ \\
\hline $1 \times 3$ & 12 & 2434.02 & $<0.001$ & 2250.50 & $<0.001$ \\
\hline $1 \times 4$ & 44 & 7875.94 & $<0.001$ & 8171.86 & $<0.001$ \\
\hline $2 \times 3$ & 3 & 2081.48 & $<0.001$ & 3065.23 & $<0.001$ \\
\hline $2 \times 4$ & 11 & 1449.21 & $<0.001$ & 2912.79 & $<0.001$ \\
\hline $3 \times 4$ & 33 & 7276.98 & $<0.001$ & 8827.68 & $<0.001$ \\
\hline $1 \times 2 \times 3$ & 12 & 1279.56 & $<0.001$ & 3232.11 & $<0.001$ \\
\hline $1 \times 2 \times 4$ & 44 & 2594.12 & $<0.001$ & 5371.04 & $<0.001$ \\
\hline $1 \times 3 \times 4$ & 132 & 4569.02 & $<0.001$ & 5095.57 & $<0.001$ \\
\hline $2 \times 3 \times 4$ & 33 & 1694.28 & $<0.001$ & $18,995.92$ & $<0.001$ \\
\hline
\end{tabular}


Table 3 Fungus isolates' count in relation to the type of mountain rage in the years 2013-2014

\begin{tabular}{|c|c|c|c|c|c|c|}
\hline \multirow[t]{2}{*}{ Fungus species } & \multicolumn{5}{|c|}{ Sample collection site } & \multirow[t]{2}{*}{ Aggregates } \\
\hline & Śnieżka & Palenica & Babia Góra & Kasprowy & Tarnica & \\
\hline Alternaria alternata & 3 & 49 & 294 & 813 & 146 & 1305 \\
\hline Auerobasidium pullulans & 16 & 13 & 3 & 14 & 4 & 50 \\
\hline Cladosporium cladosporioides & 120 & 1752 & 3974 & 99 & 453 & 6398 \\
\hline Cladosporium herbarum & 101 & 3 & 4 & 276 & 128 & 512 \\
\hline Fusarium equiseti & 3 & 3 & 8 & 4 & 15 & 33 \\
\hline Gliocladium catenulantum & 23 & 422 & 4 & 48 & 242 & 739 \\
\hline Penicillium notatum & 45 & 122 & 62 & 12 & 30 & 271 \\
\hline Penicillium purpurgenum & 3 & 2 & 3 & 3 & 41 & 52 \\
\hline Penicillium waksmani & 9 & 74 & 4 & 14 & 68 & 169 \\
\hline Penicillium vermiculatum & 16 & 16 & 253 & 4 & 43 & 332 \\
\hline Sclerotinia sclerotiorium & 8 & 82 & 16 & 4 & 28 & 138 \\
\hline Trichotecium roseum & 3 & 27 & 3 & 3 & 4 & 40 \\
\hline aggregates & 350 & 2565 & 4628 & 1294 & 1202 & 10,039 \\
\hline
\end{tabular}

A. alternata, compared with the other mountain peaks. A great distance between the points representing 'Babia Góra' and Śnieżka confirms that the fluctuations in the concentrations of the 12 fungus species under study embrace a rich diversity of patterns. The atmospheric conditions around Babia Góra were instrumental in the substantial increase in the number of the spores, which was not true for Śnieżka.
The analysis of the variations within the fungus population, attributable to the year, season or the mountain range, reveals three groups of species which differ enormously from one another (Fig. 3). The first, one-element, group is situated at a considerable distance from other groups and is formed by A. alternata. Compared with other fungi, this one exhibits quite a different pattern of fluctuations in the spore count for each

Table 4 Fungus isolates' count in relation to the type of mountain rage in the years 2014-2015

\begin{tabular}{|c|c|c|c|c|c|c|}
\hline \multirow[t]{2}{*}{ Fungus species } & \multicolumn{5}{|c|}{ Sample collection site } & \multirow[t]{2}{*}{ Aggregates } \\
\hline & Śnieżka & Palenica & Babia Góra & Kasprowy & Tarnica & \\
\hline Alternaria alternata & 48 & 200 & 55 & 882 & 75 & 1260 \\
\hline Auerobasidium pullulans & 2 & 41 & 9 & 3 & 116 & 171 \\
\hline Cladosporium cladosporioides & 413 & 790 & 426 & 485 & 759 & 2873 \\
\hline Cladosporium herbarum & 4 & 114 & 29 & 10 & 221 & 378 \\
\hline Fusarium equiseti & 16 & 48 & 128 & 75 & 338 & 605 \\
\hline Gliocladium catenulantum & 15 & 74 & 1946 & 82 & 142 & 2259 \\
\hline Penicillium notatum & 160 & 73 & 16 & 23 & 49 & 321 \\
\hline Penicillium purpurgenum & 23 & 35 & 28 & 16 & 3 & 105 \\
\hline Penicillium waksmani & 49 & 75 & 23 & 9 & 76 & 232 \\
\hline Penicillium vermiculatum & 56 & 29 & 9 & 10 & 4 & 108 \\
\hline Sclerotinia sclerotiorium & 30 & 42 & 17 & 83 & 75 & 247 \\
\hline Trichotecium roseum & 4 & 61 & 17 & 21 & 43 & 146 \\
\hline Aggregates & 820 & 1582 & 2703 & 1699 & 1801 & 8605 \\
\hline
\end{tabular}


Table 5 Fungus isolates' count in relation to the season in the years 2013-2014

\begin{tabular}{|c|c|c|c|c|c|}
\hline \multirow[t]{2}{*}{ Fungus species } & \multicolumn{4}{|c|}{ Seasons of the year } & \multirow[t]{2}{*}{ Aggregates } \\
\hline & Summer & Autumn & Winter & Spring & \\
\hline Alternaria alternata & 1173 & 34 & 2 & 96 & 1305 \\
\hline Auerobasidium pullulans & 28 & 14 & 3 & 5 & 50 \\
\hline Cladosporium cladosporioides & 5183 & 567 & 89 & 559 & 6398 \\
\hline Cladosporium herbarum & 221 & 283 & 5 & 3 & 512 \\
\hline Fusarium equiseti & 5 & 3 & 3 & 22 & 33 \\
\hline Gliocladium catenulantum & 4 & 682 & 4 & 49 & 739 \\
\hline Penicillium notatum & 37 & 17 & 110 & 107 & 271 \\
\hline Penicillium purpurgenum & 24 & 22 & 4 & 2 & 52 \\
\hline Penicillium waksmani & 31 & 26 & 16 & 96 & 169 \\
\hline Penicillium vermiculatum & 82 & 230 & 4 & 16 & 332 \\
\hline Sclerotinia sclerotiorium & 30 & 42 & 4 & 62 & 138 \\
\hline Trichotecium roseum & 30 & 4 & 4 & 2 & 40 \\
\hline aggregates & 6848 & 1924 & 248 & 1019 & 10,039 \\
\hline
\end{tabular}

season, year or mountain range. Another group includes G. catenulantum, C. cladosporioides and $P$. vermiculatum, in which the fluctuations in the count of the spores follow a more or less uniform pattern. The last group comprises $T$. roseum, $S$. sclerotiorium, $C$. herbarium, F. equiseti, P. purpurgenum, P. waksmani, A. pullulans and P. notatum and is more diffuse.

\section{Discussion}

In this day and age, when the changes affect climate and habitat, and when habitat and the environment are irreversibly fragmented, it is imperative that we undertake environmental research studies to forecast, to a lesser or greater extent, the changes occurring in nature (Smith 1994; de Groot et al. 1995). One such group of

Table 6 Fungus isolates' count in relation to the season in the years 2014-2015

\begin{tabular}{|c|c|c|c|c|c|}
\hline \multirow[t]{2}{*}{ Fungus species } & \multicolumn{4}{|c|}{ Seasons of the year } & \multirow[t]{2}{*}{ Aggregates } \\
\hline & Summer & Autumn & Winter & Spring & \\
\hline Alternaria alternata & 973 & 247 & 35 & 5 & 1260 \\
\hline Auerobasidium pullulans & 5 & 14 & 24 & 28 & 71 \\
\hline Cladosporium cladosporioides & 962 & 1226 & 399 & 286 & 2873 \\
\hline Cladosporium herbarum & 198 & 43 & 89 & 48 & 378 \\
\hline Fusarium equiseti & 177 & 331 & 1 & 96 & 605 \\
\hline Gliocladium catenulantum & 3 & 2008 & 16 & 232 & 2259 \\
\hline Penicillium notatum & 116 & 166 & 5 & 34 & 321 \\
\hline Penicillium purpurgenum & 5 & 81 & 18 & 1 & 105 \\
\hline Penicillium waksmani & 5 & 162 & 36 & 29 & 232 \\
\hline Penicillium vermiculatum & 17 & 51 & 24 & 16 & 108 \\
\hline Sclerotinia sclerotiorium & 64 & 174 & 4 & 5 & 247 \\
\hline Trichotecium roseum & 120 & 4 & 4 & 18 & 146 \\
\hline aggregates & 2645 & 4507 & 655 & 798 & 8605 \\
\hline
\end{tabular}


Fig. 2 Correspondence analysis of the fluctuations in the population of fungi in each mountain range

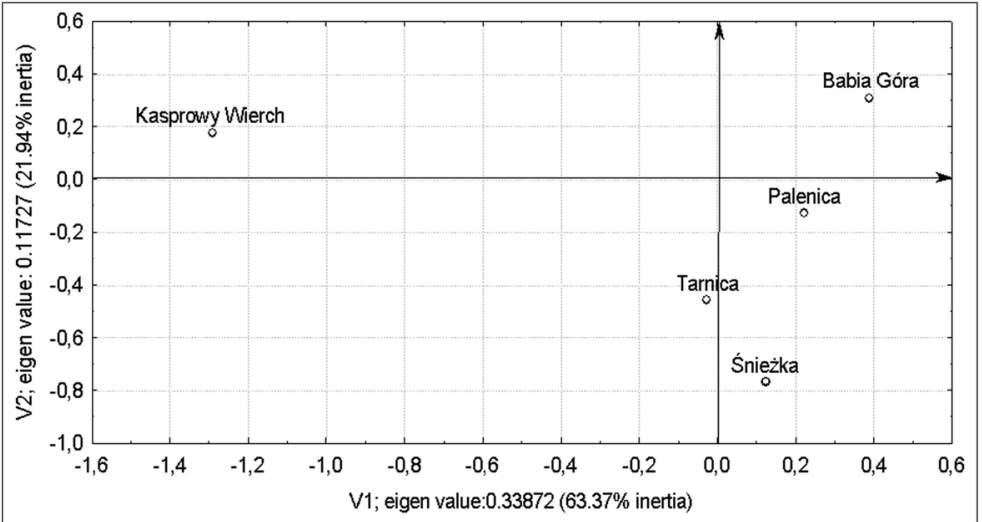

organisms, which is becoming more and more crucial in the environmental monitoring and human biomonitoring, is fungi (Porca et al. 2011; Jędryczko 2014; Kokurewicz et al. 2016; Pusz 2016).

Fungi play a prominent role in economy and environmental health. Plant pathogens are known not only to contribute to a poor crop but also to produce mycotoxins harmful to humans and animals alike (Jędryczko 2014; Gołębiowska et al. 2016). In the spirit of integrated plant protection (Norris et al. 2003), aeromycological monitoring can be justifiably required not only in agriculture (Jędryczko 2014) or forestry (Clarke 1995) but also in protected areas (Pusz et al. 2013), where plant diseases may pose threat to rare and endangered species (Pusz 2016). It is therefore vital that the rules for permanent aeromycological monitoring, especially in extreme environments such as mountainous areas, are drawn up taking into account the rapidly changing atmospheric conditions (Bonello and Blodgett 2003; Pusz et al. 2013).
In this research, the highest numbers of fungus species were observed in summer and autumn, which is corroborated by other authors (Asan et al. 2004; Almaguer-Chávez et al. 2012). The most dominant fungus in all the locations was C. cladosporioides. The fungus is popularly classified as a truly cosmopolitan organism, fairly flexible in terms of temperature but exhibiting a preference for higher air humidity accompanied by lower temperatures. It usually develops as a saprotroph deriving nourishment from dead plants. It may also turn pathogen par excellence for several living plants (Ogórek et al. 2012). The fungi belonging to the genus Cladosporium frequently colonise the seeds of many other plants, a fact confirmed by several authors (Fakhrunnisa and Ghaffar 2006; Pusz 2009).

The typical plant pathogens were strongly represented by the fungi of the genera Fusarium and S. sclerotiorium. The former pose an acute problem
Fig. 3 Correspondence analysis of the variations in each fungus species in relation to the type of mountain range and season of the year

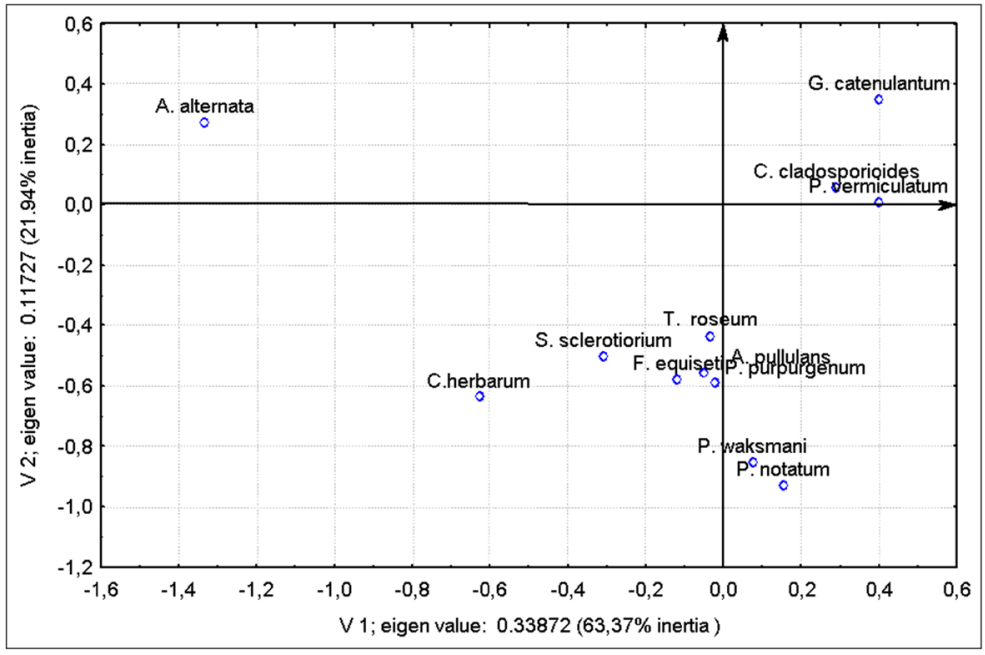


not only for agriculture, as they infect cereals and other cultivated plants (Gołębiowska et al. 2016), but also for plants growing wild (Pusz 2016). They may additionally colonise dead plants and thus constitute threat to farm animals (Pusz 2016). Another threat is posed by mycotoxins present in plant products as well as in the air (Cabral 2012). By contrast, S. sclerotorium, which causes white mould, is a polyphage which severely affects a great number of plants (Bolton et al. 2006). The presence of these species in the bioaerosol was confirmed also in the work of Pusz et al. (2013). By tracking the fluctuations in the levels of CFU, it may become feasible to predict their impact on both agricultural crops and woodland or ornamental tree nurseries. Atmospheric conditions such as wind and also temperature or precipitation should be additionally taken into account; rain appears to be, together with wind, one of the key factors affecting the concentration levels of airborne fungal spores (Jones and Harrison 2004). It is a salient fact that precipitation is likely to lead to a raised spore count, including plant pathogens (Huffman et al. 2013).

Another issue to address when establishing guidelines for aeromycological monitoring is the method of sample collection. A very common one relies on the Hirst apparatus, which draws the air in for a number of days, e.g. seven, at a fixed volume, e.g. $10 \mathrm{l}$, at an interval of several dozen minutes. This is followed by the removal of the tape with the spores, to count them and identify the species (Jędryczka et al. 2008; Jędryczka 2014). Another method, called impact method, uses likewise a variety of mechanical devices to draw in the air: in this case, the spores are deposited directly on petri dish containing solidified growth medium. The changing size of the fungi colony becomes visible after a couple of days (Pusz et al. 2013; Jędryczka 2014). Each method has its benefits and drawbacks. The biggest advantage of Hirst apparatus is that the observations of airborne spores can be extended over a prolonged period of time, but at the same time, the system suffers from the disadvantage of pollen, small insects and other impurities finding their way onto the tape. Conversely, the impact method offers a picture of what arrives on the dish only at the moment of taking the sample; however, the selective growth medium nourishes solely the organisms, e.g. fungi, whose concentration levels we are interested in. Furthermore, we can determine the viability of the spores and mycelium: observations which Hirst apparatus cannot facilitate in the same way (McCartney et al. 1997; Calderon et al. 2002).

Summing up, there is evidence to suggest that a systematic aeromycological monitoring, as used in agriculture and forestry or to forecast the presence of allergens, should include atmospheric conditions in the area under study, in particular wind direction and the average wind speed. Precipitation and air humidity, too, should be taken into account when designing the algorithms. Another significant factor to consider is a careful choice of the method: with the pros and cons of each, it is, at this stage, a challenging task. The use of Hirst apparatus requires unarguably regular sample collections by applying impact method to determine precisely the viability of the spores and assess their potential threat to plants. Another demanding task is to devise effective statistical methods that would allow the available data to reflect faithfully the state of the bioaerosol and would develop adequate prognostic tools. This, however, calls for further in-depth research.

\section{Conclusions}

Regardless of location, the ever-changing weather patterns in each year were the primary cause of the fluctuations in the numbers of fungal spores under study. The atmospheric conditions in the years 2014-2015 were more conducive to the reproduction and growth of $G$. catenulantum. The reverse was true for the years 2013-2014, when a significantly greater number of C. cladosporioides spores were identified, compared with the summer and autumn of 2014 and the winter and spring of 2015. The differences in the biodiversity and climate of the mountains in southern Poland were also the reason why the concentrations of fungal spores under study varied enormously. The conditions in the Karkonosze Mountains were less favourable for the fungi than the conditions in the Babia Góra Massif. Correspondence analysis revealed that the atmospheric conditions in the locations covered by the research affected $A$. alternata to a varying degree, in contrast to other species. This seems to confirm that factors such as habitat or topo-climatic conditions (especially like precipitation, temperature and wind speed) have a profound effect on the results obtained in the study and that they should be rigorously followed when laying down guidelines for aeromycological monitoring. 
Open Access This article is distributed under the terms of the Creative Commons Attribution 4.0 International License (http:// creativecommons.org/licenses/by/4.0/), which permits unrestricted use, distribution, and reproduction in any medium, provided you give appropriate credit to the original author(s) and the source, provide a link to the Creative Commons license, and indicate if changes were made.

\section{References}

Almaguer-Chávez, M., Rojas-Flores, T., Dobal-Amador, V., Batista-Mainegra, A., Rives-Rodríguez, N., Jesus-Aira, M., Hernández-Lauzardo, A. N., \& Hernández-Rodríguez, A. (2012). Aerobiological dynamics of potentially pathogenic fungi in a rice agro-ecosystem in La Habana, Cuba. Aerobiologia, 28, 177-183.

Asan, A., Ilhan, S., Sen, B., Erkara, I. P., Filik, C., Cabuk, A., Demirei, R., Ture, M., Okten, S. S., \& Tokur, S. (2004). Airborne fungi and Actinomycetes concentrations in the air of Eskisehir City (Turkey). Indoor and Built Environment, 13(1), 63-74.

Bolton, M. D., Thomma, B. P., \& Nelson, B. D. (2006). Sclerotinia sclerotiorum (Lib.) de Bary: biology and molecular traits of a cosmopolitan pathogen. Molecular Plant Pathology, 7(1), 116.

Bonello, P., \& Blodgett, J. (2003). Pinus nigra-Sphaeropsis sapinea as a model pathosystem to investigate local and systemic effects of fungal infection of pines. Physiological and Molecular Plant Pathology, 63, 249-261.

Bugajny, A., Knopkiewicz, M., Piotraszewska-Pająk, A., Sekulska-Stryjakowska, M., Stach, A., \& Filipiak, M. (2005). On the microbiological quality of the outdoor air in Poznań. Poland. Pol. J. of Environ. Stud., 14(3), 287-293.

Cabral JP (2012) Can we use indoor fungi as bioindicators of indoor air quality? Historical perspectives and open questions. Science of Total Environmental 408: 4285-4295.

Calderon, C., Ward, E., Freeman, J., \& McCartney, A. (2002). Detection of airborne fungal spores sampled by rotating-arm and Hirst-type spore traps using polymerase chain reaction assays. Journal of Aerosol Science, 33(2), 283-296.

Clarke, A. R. (1995). Integrated pest management in forestry: some difficulties in pursuing the holy-grail. Australian Forestry, 58(3), 147-150.

Dowd SC, Maier RM (1999) Aeromicrobiology. In: Environmental Microbiology, R.M Maier, I.L. Pepper, C.P. Gerba (ed.). Academic Press, San Diego.

Fakhrunnisa, M. H., \& Ghaffar, A. (2006). Seed-borne mycoflora of wheat, sorghum and barley. Pakistan Journal of Botany, 38(1), 185-192.

Gołębiowska, H., Pląskowska, E., Weber, R., \& Kieloch, R. (2016). The effect of soil tillage and herbicide treatments on the incidence of Fusarium fungi genus in the grain of rye. Plant, Soil and Environment, 62(10), 435-440.

de Groot, R. S., Ketner, P., \& Ovaa, A. H. (1995). Selection and use of bio-indicators to assess the possible effects of climate change in Europe. Journal of Biogeography, 22, 935-943.

Hill MO (1974) Correspondence analysis: a neglected multivariate method. Applied Statistics (23): 340-354
Huffman, J. A., Prenni, A. J., DeMott, P. J., Pöhlker, C., Mason, R. H., Robinson, N. H., \& Gochis, D. J. (2013). High concentrations of biological aerosol particles and ice nuclei during and after rain. Atmospheric Chemistry and Physics, 13(13), 6151.

Ianovici, N., Dumbrava-Dodoaca, M., Filimon, M. M., \& Sinitean, A. (2011). A comparative aeromycological study of the incidence of allergenic spores in outdoor environment. Ann Univ din Oradea - Fasc Biol, XVIII(1), 88-98.

Jędryczka, M. (2014). Aeromycology: studies of fungi in aeroplankton. Folia Biologica et Oecologica, 10(1), 18-26.

Jędryczka, M., Kaczmarek, J., Dawidziuk, A., \& Brachaczek, A. (2008). System for forecasting disease epidemics-aerobiological methods in Polish agriculture. Aspects of Applied Biology, 89, 65-70.

Jones, A. M., \& Harrison, R. M. (2004). The effects of meteorological factors on atmospheric bioaerosol concentrations - a review. Science of the Total Environment, 326(1), 151-180.

Klarič, M. S., \& Pepeljnjak, S. (2001). A year-round aeromycological study in Zagreb area. Croatia. Ann. Agric. Environ. Med., 13, 55-64.

Kokurewicz, T., Ogórek, R., Pusz, W., \& Matkowski, K. (2016). Bats increase the number of cultivable airborne fungi in the "Nietoperek" bat reserve in Western Poland. Microbial Ecology, 72(1), 36-48.

Kurup, V. P., Shen, H. D., \& Vijay, H. (2002). Immunobiology of fungal allergens. International Archives of Allergy and Immunology, 129, 181-191.

Leyronas, C., \& Nicot, P. C. (2012). Monitoring viable airborne inoculum of Botrytis cinerea in the South-East of France over 3 years: relation with climatic parameters and the origin of air masses. Aerobiologia, 29, 291-299.

Magyar, D., Szöke, C., Koncz, Z., Szécsi, A., \& Bobvos, J. (2012). Identification of airborne propagules of the Gibberella fujikuroi species complex during maize production. Aerobiologia, 28, 263-271.

McCartney, H. A., Fitt, B. D., \& Schmechel, D. (1997). Sampling bioaerosols in plant pathology. Journal of Aerosol Science, 28(3), 349-364.

Meredith, D. S. (1973). Significance of spore release and dispersal mechanism in plant disease epidemiology. Annual Review of Phytopathology, 11, 313-342.

Nagarajan, S., \& Saharan, M. S. (2007). Epidemiology of Puccinia triticina in Gangetic Plain and planned containment of crop losses. Wheat Production in Stressed Environments, Developments in Plant Breeding, 12, 71-76.

Norris, R. F., Edward, P., Caswell, C., \& Kogan, M. (2003). Concepts in integrated pest management (Vol. 1). Upper Saddle River, NJ: Prentice Hall.

Ogórek, R., Lejman, A., Pusz, W., Miłuch, A., \& Miodyńska, P. (2012). Characteristics and taxonomy of Cladosporium fungi. Medical Mycology, 19(2), 80-85.

Palmas, F., \& Cosentino, S. (2009). Comparison between fungal airspore concentration at two different sites in the South of Sardinia. Grana, 29(1), 87-95.

Palti, J., \& Cohen, Y. (1980). Downy mildew of Cucurbits (Pseudoperonospora cubensis): the fungus and its hosts, distribution, epidemiology and control. Phytoparasitica, 2, 109-147. 
Pepeljnjak, S., \& Šegvič, M. (2003). Occurrence of fungi in air and on plants in vegetation of different climatic regions in Croatia. Aerobiologia, 19, 11-19.

Pitt, J. I., \& Hocking, A. D. (2009). Fungi and food spoilage (320 pp). New York: Springer.

Porca, E., Jurado, V., Martin-Sanchez, P. M., Hermosin, B., Bastian, F., Alabouvette, C., \& Saiz-Jimenez, C. (2011). Aerobiology: an ecological indicator for early detection and control of fungal outbreaks in caves. Ecological Indicators, $11,1594-1598$.

Pusz, W. (2009). Fungi from seeds of Amaranthus spp. Phytopathologia, 54, 15-21.

Pusz, W. (2016). Plants' healthiness assessment as part of the environmental monitoring of protected mountainous area in the example of Karkonosze (Giant) Mts. (SW Poland). Environmental Monitoring and Assessment, 188(10), 1-15.

Pusz, W., Kita, W., Dancewicz, A., \& Weber, R. (2013). Airborne fungal spores of subalpine zone of the Karkonosze and Izerskie Mountains (Poland). Journal of Mountain Sciences, 10(6), 940-952.

Pusz, W., Pląskowska, E., Weber, R., \& Kita, W. (2015). Assessment of the abundance of airborne fungi in cattle barn of dairy farm. Polish Journal of Environmental Studies, 24(1), 241-248.

Raisi, L., Aleksandropoulu, V., Lazaridis, M., \& Katsivela, E. (2012). Size distribution of viable, cultivable, airborne microbes and their relationship to particulate matter concentration and meteorological conditions in a Mediterranean site. Aerobiologia, 29, 233-238.

Smith, R. L. (1994). Vascular plants as bioindicators of regional warming in Antarctica. Oecologia, 99(3-4), 322-328.

Tomassetti, B., Lombardi, A., Cerasani, E., Di Sabatino, A., Pace, L., Ammazzalorso, D., \& Verdecchia, M. (2011). Mapping of Alternaria and Pleospora concentrations in Central Italy using meteorological forecast and neural network estimator. Aerobiologia, 29, 55-70.

Topbas, M., Tosun, I., Can, G., Kaklikkaya, N., \& Aydin, F. (2006). Identification and seasonal distribution of airborne fungi in urban outdoor air in an Eastern Black Sea Turkish Town. Turk. J. Med. Sci., 36, 31-36.

Vaish, S. S., Ahmed, S. B., \& Prakash, K. (2011). First documentation on status of barley diseases from the high altitude cold arid Trans-Himalayan Ladakh region of India. Crop Protection, 30, 1129-1137.

Watanabe, T. (2011). Pictorial atlas of soil and seed fungi: morphologies of cultured fungi and key to species (420 pp). Washington: CRC Press.

Xia, Y., Conen, F., \& Alewell, C. (2012). Total bacterial number concentration in free tropospheric air above the Alps. Aerobiologia, 29, 153-159. 